\title{
The KPC type $\beta$-lactamases: new enzymes that confer resistance to carbapenems in Gram-negative bacilli
}

\section{Pawel Sacha $^{1}$, Alina Ostas ${ }^{2}$, Jadwiga Jaworowska ${ }^{3}$, Piotr Wieczorek ${ }^{1}$, Dominika Ojdana $^{1}$, Jerzy Ratajczak ${ }^{2}$, Elżbieta Tryniszewska ${ }^{1}$}

\author{
${ }^{1}$ Department of Microbiological Diagnostics, Medical University of Bialystok, Poland \\ ${ }^{2}$ Department of Anesthesiology and Intensive Care, Institute of Hematology and Transfusion Medicine, \\ Warsaw \\ ${ }^{3}$ Department of Microbiological Diagnostics, University Hospital of Bialystok, Poland
}

\begin{abstract}
Antimicrobial resistance due to the continuous selective pressure from widespread use of antimicrobials in humans, animals and agriculture has been a growing problem for last decades. KPC $\beta$-lactamases hydrolyzed $\beta$-lactams of all classes. Especially, carbapenem antibiotics are hydrolyzed more efficiency than other $\beta$-lactam antibiotics. The KPC enzymes are found most often in Enterobacteriaceae. Recently, these enzymes have been found in isolates of Pseudomonas aeruginos $a$ and Acinetobacter spp. The observations of $b l a_{\mathrm{KPC}}$ genes isolated from different species in other countries indicate that these genes from common but unknown ancestor may have been mobilized in these areas or that $b l a_{\mathrm{KPC}}$-carrying bacteria may have been passively by many vectors. The emergence of carbapenem resistance in Gram-negative bacteria is worrisome because the carbapenem resistance often may be associated with resistance to many $\beta$-lactam and non- $\beta$-lactam antibiotics. Treatment of infections caused by KPC-producing bacteria is extremely difficult because of their multidrug resistance, which results in high mortality rates. Therapeutic options to treat infections caused by multiresistant Gram-negative bacteria producing KPC-carbapenemases could be used polymyxin B or tigecycline.
\end{abstract}

Key words: KPC type carbapenemases, epidemiology, molecular genetics

\section{Introduction}

Carbapenem antibiotics such as imipenem and meropenem are important therapeutic agents in the health care setting. Because these drugs have broadspectrum activity, they are frequently recommended as first-line therapy for serve infections caused by extended spectrum $\beta$-lactamase (ESBL) - producing Enterobacteriaceae and multi-drug-resistant (MDR) Gram-negative bacilli, such as Pseudomonas aeruginosa and Acinetobacter spp. The carbapenem group of antibiotics is often considered as the last resort treatment for nosocomial infections caused by MDR Gram-negative organisms [1,2].

Resistance to carbapenems in Gram-negative pathogens was frequently due hyperproduction of AmpC $\beta$-lactamases associated with a loss of outer

Correspondence: P.Sacha, Dept. of Microbiological Diagnostics, Medical University of Bialystok, Waszyngtona Str. 15A, 15-269 Bialystok, Poland; tel./fax.: (+4885) 7468571, e-mail: sachpt@umwb.edu.pl membrane proteins [3], increased expression of efflux pumps systems [4], and changes in the affinity of penicillin-binding proteins (PBPs) for carbapenems [5]. The recent emergence and spread of acquired carbapenem resistance are of great concern [6].

However, in recent years, there have been reports of carbapenemase-resistant Gram-negative bacteria producing different types of carbapenemases in Asian and some American, European and Near East regions [7-14]. Novel reported Class A enzymes with carbapenemase activity are KPC serine $\beta$-lactamases (Klebsiella Pneumoniae Carbapenemase) [9,14].

The KPC - enzymes: characteristics and epidemiology

Carbapenem-hydrolyzing KPC $\beta$-lactamases are a group of recently identified carbapenemases that belong to Bush group 2f, molecular class A $[15,16]$. Serine carbapenemases such as KPC are unique among the class A $\beta$-lactamases because containing a substituent at the $\alpha$ position of the carbon atom in the 
Table 1. Acquired $\beta$-carbapenemases $\left(\mathrm{ESBL}_{\mathrm{CARBA}}\right)$ with hydrolytic activity against carbapenems and extended-spectrum cephalosporins.

\begin{tabular}{|c|c|c|c|}
\hline l'unctional mechanism & $\begin{array}{c}\text { Giske } \\
\text { (Groups) }\end{array}$ & Lxamples & Detected methods \\
\hline Serine $\beta$-lactamases & FSBI ${ }_{\text {C } \triangle R B \Lambda-\Lambda}$ & KPC; GFS-2, $-4,-5,-6,-8 ;$ NMC; SMF; IMT-1, -2 & \multirow{3}{*}{$\begin{array}{l}\text { Phenolypic } \\
\text { or genotypic }\end{array}$} \\
\hline Mctallo- $\beta$-lactamases & LSBL ${ }_{\text {CARBA-B }}(\mathrm{MLL})$ & IMP; VIM; SPM-1; GIM-1; SIM-1; AIM-1 & \\
\hline Scrine $\beta$-lactamases & $\begin{array}{l}\text { LSBL } \text { CARB-D } \\
\text { (OX } \text {-carbapenemases) }\end{array}$ & OXA-28-group; OXA-24-group; OXA-48; OXA-58-group & \\
\hline
\end{tabular}

$\beta$-lactam ring adjacent to the carbonyl $[17,18]$. In common with other class A $\beta$-lactamases, these highly proficient class A enzymes have an efficient hydrolysis mechanisms involving a catalytic residue (S70), which acylates $\beta$-lactam substrates, and a well-positioned deacylation water. KPC enzymes have the conserved active-site motifs S-X-X-K, and K-T-G of the class A $\beta$-lactamases and have the closet amino acid identity $(\sim 45 \%)$ to the SME carbapenemases. The KPC enzymes seem to differ from the rest of the group $2 f$ (SME, NMC- A, IMI-1) $[16,19]$ in that they hydrolyze oxyimino-cephalosporins more efficiently. These enzymes are capable of hydrolyzing penicillins, cephalosporins and aztreonam, and are weakly inhibited by clavulanic acid and tazobactam [20]. The KPC enzymes can also confer resistance to all carbapenems, such as, meropenem, imipenem, ertapenem and doripenem [21]. Their current spread worldwide makes them a potential threat to currently available antibiotic-based treatments.

New classification for different acquired $\beta$-carbapenemases $\left(\mathrm{ESBL}_{\mathrm{CARB}}\right)$ proposed by Giske et al. [22] we presented in Table 1.

Nine different subtypes KPC-enzyme have been reported, KPC-1 to KPC-10 [23]. The genes encoding KPC-1 and KPC-2 were found to be identical $[20,24]$.

The first report of one of these $\beta$-lactamases, KPC1/2, was from carbapenem-resistant Klebsiella pneumoniae isolated in North Carolina, USA, in 2001 [20].

The second report of a KPC- $1 / 2$ producing isolate was a Klebsiella oxytoca. The bla $a_{\mathrm{KPC}-1 / 2}$ determinant of $K$. oxytoca was located on a $70-\mathrm{kb}$ conjugative plasmid that also encodes SHV-46, TEM-1. This plasmid was encoded resistance to gentamicin and tobramycin. The amino acid sequences inferred from DNA sequencing of the upstream region suggests that the $\mathrm{KPC}-1 / 2$-encoding plasmid was $98 \%$ identical to the plasmid identified in the Salmonella serotype Cubana strain [25].

In United States, the first report KPC- $1 / 2$ producing clinical isolate from outside family Enterobacteriaceae was described in 2009. The bla $a_{\mathrm{KPC}-1 / 2}$ gene was identified in Pseudomonas putida isolated from blood cultures in University Hospital in Texas [26].

Outside of the United States the first case KPC-1/2 producing bacteria was reported in France [27], and more recently, cases were reported in Colombia [28,29], China [30] and in Israel [8]. First Klebsiella pneumoniae $\mathrm{KPC}-1 / 2$ producing isolate in China was reported in 2007 [30]. Recently, in China, KPC-1/2 enzymes were reported in other species Enterobacteriaceae (Serratia marcescens, Escherichia coli and Citrobacter freundii) $[31,32,33]$.

The first identification of a chromosomally encoded $b l a_{\mathrm{KPC} 1 / 2}$ gene was described in Pseudomonas aeruginosa in Colombia [29].

Presently, KPC-1/2 carbapenemases have been reported among many species Gram-negative bacteria isolated in different countries of the world [8,2930,34-39]. Soon afterward, KPC-3 was founded in Klebsiella pneumoniae [39] and in other Enterobacteriaceae isolated in USA [11,40-42]. KPC-3 has never been reported outside the USA, until 2007. Outside USA, the first carbapenem-resistant isolate Klebsiella pneumoniae carried the $b l a_{\mathrm{KPC}-3}$ gene was reported by Leavit et al. [43], in patient hospitalized in Tel Aviv Medical Center (Israel).

The substrate profiles for the KPC-3 and KPC- $1 / 2$ are very similar, although the catalytic efficiency of KPC-3 is somewhat higher with some substrates, including oximinocephalosporins and carbapenems. The catalytic activity with ceftazidime is approximately 30 times higher than the KPC-1/2 enzyme [44].

KPC $-1 / 2$ and KPC-3 are widespread in USA and correspond to the most frequent carbapenemases isolated from Enterobacteriaceae [11,20,39,41-43,45-47].

Next enzyme from these group $\beta$-lactamases, KPC4 carbapenemase have been detected in Enterobacter spp., in Scotland [39] and recently in Klebsiella pneumoniae from Puerto Rico [49].

A novel Klebsiella pneumoniae carbapenemase (KPC-5) variant, designated bla $a_{\mathrm{KPC}-5}$, was discovered in the three carbapenem-resistant Pseudomonas aeruginosa clinical isolates from Puerto Rico [50].

KPC-5 and KPC-4 used in these studies were more efficient at hydrolyzing ceftazidime than KPC-2. In addition, KPC-5 was slightly more activity against imipenem ( 1.7-fold) than KPC-4.

Epidemiology of the KPC enzymes and species producing these enzymes we presented in table 2. For the two last periods have been identified five new KPC-enzymes (KPC-6 to KPC-10), but reports have 
Table 2. KPC-type $\beta$-carbapenemases.

\begin{tabular}{|c|c|c|c|c|c|}
\hline Enzyme $^{1}$ & $\begin{array}{c}\text { Nucleotide }^{2} \\
\text { (accession no.) }\end{array}$ & Organisms (source) & Genetic location & Country & Reference \\
\hline $\mathrm{KPC}-1 *$ & AF297554 & Klebsiella pneumoniae & $\mathrm{pl}$ & USA & {$[20]$} \\
\hline $\mathrm{KPC}-1 / 2 *$ & AY034847 & Klebsiella pneumoniae & $\mathrm{pl}$ & USA & {$[46]$} \\
\hline $\mathrm{KPC}-1 / 2 *$ & AY210886 & Klebsiella oxytoca & $\mathrm{pl}$ & USA & {$[25]$} \\
\hline $\mathrm{KPC}-1 / 2 *$ & DQ897687 & Klebsiella pneumoniae & $\mathrm{pl}$ & China & [30] \\
\hline $\mathrm{KPC}-1 / 2 *$ & DQ523564 & Klebsiella pneumoniae & $\mathrm{pl}$ & Colombia & [28] \\
\hline $\mathrm{KPC}-1 / 2 *$ & AF481906 & Salmonella enterica & $\mathrm{pl}$ & USA & [47] \\
\hline $\mathrm{KPC}-1 / 2 *$ & DQ899729 & Serratia marcescens & $\mathrm{pl}$ & China & [32] \\
\hline $\mathrm{KPC}-1 / 2 *$ & - & Citrobacter freundii & $\mathrm{pl}$ & Colombia & [29] \\
\hline $\mathrm{KPC}-1 / 2 *$ & - & Klebsiella pneumoniae & $\mathrm{pl}$ & USA & {$[65]$} \\
\hline $\mathrm{KPC}-1 / 2 *$ & - & Citrobacter freundii & $\mathrm{pl}$ & USA & {$[11,58]$} \\
\hline $\mathrm{KPC}-1 / 2 *$ & - & Proteus mirabilis & $\mathrm{pl}$ & USA & {$[48]$} \\
\hline $\mathrm{KPC}-1 / 2 *$ & - & Enterobacter spp. & (nr) & Israel & [34] \\
\hline $\mathrm{KPC}-1 / 2 *$ & - & Pseudomonas aeruginosa & $\mathrm{pl} / \mathrm{ch}$ & Colombia & [29] \\
\hline $\mathrm{KPC}-1 / 2 *$ & - & Klebsiella oxytoca & $\mathrm{pl}$ & USA & [58] \\
\hline $\mathrm{KPC}-1 / 2 *$ & - & Escherichia coli & (nr) & USA & [11] \\
\hline $\mathrm{KPC}-1 / 2 *$ & - & Serratia marcescens & $\mathrm{pl}$ & China & [31] \\
\hline $\mathrm{KPC}-1 / 2 *$ & - & Escherichia coli & $\mathrm{pl}$ & China & [31] \\
\hline $\mathrm{KPC}-1 / 2 *$ & - & Klebsiella pneumoniae & $\mathrm{pl}$ & China & [31] \\
\hline $\mathrm{KPC}-1 / 2 *$ & - & Klebsiella pneumoniae & $\mathrm{pl}$ & Israel & [43] \\
\hline $\mathrm{KPC}-1 / 2 *$ & - & Escherichia coli & $\mathrm{pl}$ & Israel & [8] \\
\hline $\mathrm{KPC}-1 / 2 *$ & - & Enterobacter spp. & $\mathrm{pl}$ & USA & {$[52]$} \\
\hline $\mathrm{KPC}-1 / 2 *$ & - & Klebsiella pneumoniae & (nr) & Greece & {$[35,36]$} \\
\hline $\mathrm{KPC}-1 / 2 *$ & - & Enterobacter hormaechei & (nr) & USA & [42] \\
\hline $\mathrm{KPC}-1 / 2 *$ & - & Enterobacter cloacae & $\mathrm{pl}$ & Israel & {$[55]$} \\
\hline $\mathrm{KPC}-1 / 2 *$ & - & Enterobacter cloacae & (nr) & USA & [41] \\
\hline $\mathrm{KPC}-1 / 2 *$ & - & Pseudomonas putida & (nr) & USA & [26] \\
\hline $\mathrm{KPC}-1 / 2 *$ & - & Enterobacter aerogenes & (nr) & USA & {$[41]$} \\
\hline $\mathrm{KPC}-1 / 2 *$ & - & Klebsiella pneumoniae & (nr) & Brazil & {$[37,56]$} \\
\hline $\mathrm{KPC}-1 / 2 *$ & - & Escherichia coli & $\mathrm{pl}$ & France & {$[38]$} \\
\hline $\mathrm{KPC}-1 / 2 *$ & - & Enterobacter cloacae & $\mathrm{pl}$ & France & [38] \\
\hline $\mathrm{KPC}-1 / 2 *$ & - & Klebsiella pneumoniae & $\mathrm{pl}$ & France & [27] \\
\hline KPC-3 & AF395881 & Klebsiella pneumoniae & $\mathrm{pl}$ & USA & [39] \\
\hline $\mathrm{KPC}-3$ & AY522950 & Enterobacter cloacae & (nr) & USA & {$[41]$} \\
\hline $\mathrm{KPC}-3$ & - & Klebsiella pneumoniae & $\mathrm{pl}$ & USA & {$[40,45]$} \\
\hline KPC-3 & - & Klebsiella pneumoniae & $\mathrm{pl}$ & USA & {$[57]$} \\
\hline $\mathrm{KPC}-3$ & - & Enterobacter gergoviae & (nr) & USA & {$[41]$} \\
\hline $\mathrm{KPC}-3$ & - & Escherichia coli & (nr) & USA & {$[42]$} \\
\hline KPC-3 & - & Klebsiella pneumoniae & $\mathrm{pl}$ & Israel & [43] \\
\hline KPC-3 & - & Citrobacter freundii & (nr) & USA & [11] \\
\hline KPC-3 & - & Serratia marcescens & (nr) & USA & [41] \\
\hline KPC-4 & AY700571 & Enterobacter cancerogenus & (nr) & Scotland & {$[50]$} \\
\hline KPC-4 & - & Klebsiella pneumoniae & $(\mathrm{nr})$ & Puerto Rico & [49] \\
\hline KPC-5 & EU400222 & Pseudomonas aeruginosa & Tn5563 & Puerto Rico & {$[50]$} \\
\hline KPC-6 & EU555534 & Klebsiella pneumoniae & $(\mathrm{nr})$ & Puerto Rico & none \\
\hline KPC-7 & EU729727 & Klebsiella pneumoniae & $(\mathrm{nr})$ & USA & none \\
\hline KPC-8 & FJ234412 & Klebsiella pneumoniae & $(\mathrm{nr})$ & Puerto Rico & none \\
\hline KPC-9 & FJ624872 & Escherichia coli & (nr) & Israel & none \\
\hline KPC-10 & GQ140348 & Acinetobacter baumannii & (nr) & Puerto Rico & none \\
\hline
\end{tabular}

Abbreviations: pl - plasmid; ch - chromosome; (nr) - not reported; none - unpublished; Tn5563 - transposon. ${ }^{1} \mathrm{KPC}$-type $\beta$-Lactamases: Available at: http://www.lahey.org/Studies/other.asp.[23]. ${ }^{2}$ According to GenBank database: Available at: http://www.ncbi.nlm.nih.gov/Genbank/index.html.

* Sequence of KPC-1 is identical to that of KPC-2 [24]. 
been unpublished [Available at: http://www.ncbi.nlm. nih.gov/Genbank/index.html .].

\section{Molecular characterization of $b l a_{\mathrm{KPC}}$ genes encoded KPC carbapenemases}

The rapid spread of $b l a_{\mathrm{KPC}}$ genes can be attributed in part to their mobility and presence on plasmids or transposons [20,25,27,30-33,35,46-47,51-54]. The $b l a_{\mathrm{KPC}}$ genes have usually been identified in large plasmids. These plasmids also carry aminoglycoside resistance determinants, and have been associated with other antibiotic-resistance genes such as the most widespread ESBL genes or quinolones-resistance determinants (QnrA, QnrB) [25,31,40,55-57].

Recently Rasheed et al. [58] was described a ca.95$\mathrm{kp} b l a_{\mathrm{KPC}}$-carrying plasmid that was common to two different species of Enterobacteriaceae (Citrobacter freundii and Klebsiella oxytoca) isolated in the same hospital. The $b l a_{\mathrm{KPC}-1 / 2}$ gene was located on $10 \mathrm{~kb}$ Tn3-type transposon (named Tn4401) and was identified on plasmids of different size. This transposon possesses two unrelated insertion sequences (IS) elements ISKpn 6 and ISKpn 7. This phenomenon suggesting that the gene can also move into different plasmids by insertion transposon. Genetic structure (in detail) was described in Klebsiella pneumoniae in France [53].

The KPC- $1 / 2$ enzyme showed $45 \%$ amino acid identity to SME-1[59] from Serratia marcescens S6 [20]. Unlike KPC-1/2 the other three class A carbapenemases (NMC-A, IMI-1 and SME-1) showed $>90 \%$ similarity to each other at the nucleotide level $[59,60]$. The nearest phylogenetically related enzyme to the KPC is another class A carbapenemase, SFC-1, isolated from Serratia fonticola [61].

In a single case, the $b l a_{\mathrm{KPC}-1 / 2}$ gene has been reported both at a chromosomal and plasmid location in Pseudomonas aeruginosa [29].

In 2004, Woodford et al. [39] was characterized sequence of the KPC-3 gene obtained from Klebsiella pneumoniae. The product contained an open reading frame (ORF) of 882 bp encoding 293 amino acids, with one nucleotide change not present in $b l a_{\mathrm{KPC}-1 / 2}$ gene. This mutation was results changes in amino acid substitution of $\mathrm{His}(272) \rightarrow \mathrm{Tyr}$.

Recently, Rice et al. [57] was described a novel genetic element represents a coalescence of genes $b l a_{\mathrm{KPC}-3}$ and $q n r B 19$. Both genes were localized on large plasmid. This genetic structure was named KQ (KPC and ORN) element. The KQ element is built on backbone of Tn3-family transposon Tn1331. The firstTn 1331 has been reported by Sarno et al. [62]. $\operatorname{Tn} 1331$ has now served as the backbone into which mobile elements conferring resistance to carbapenem (Tn4401) and fluoroquinolones (Tn5387) have inserted. The KQ element is mobile because the insertion of

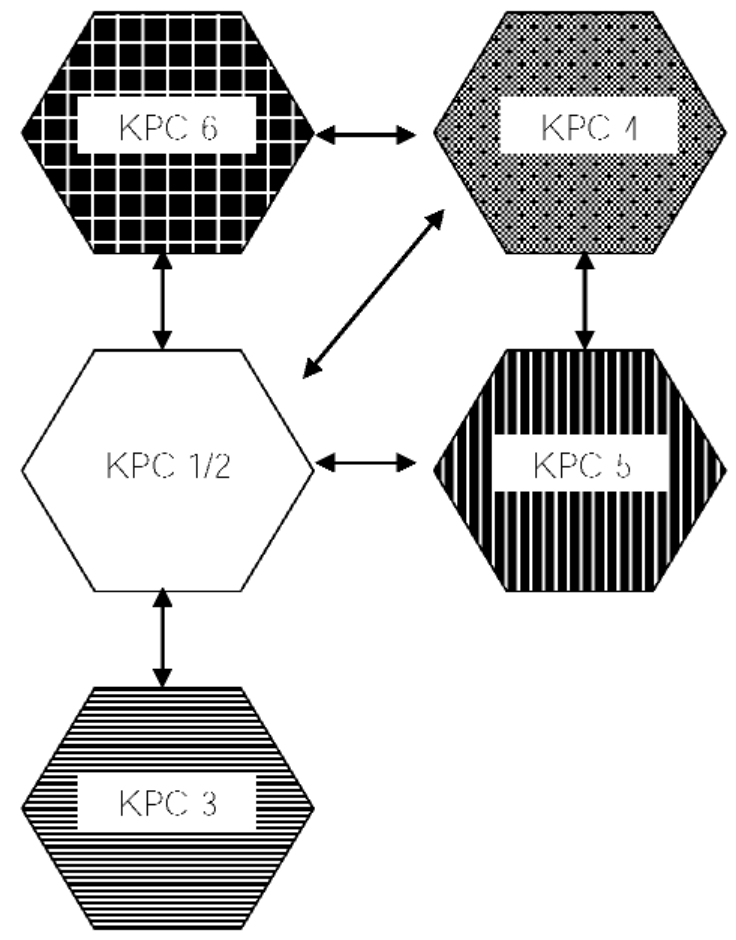

Fig. 1. The genetic relationships of the KPC-type $\beta$-carbapenemase variants.

Tn4401 into Tn1331 would presumably affect transposability [57].

KPC-5 enzyme was discovered in Pseudomonas aeruginosa in Puerto Rico. Characterization of the upstream region of $b l a_{\mathrm{KPC}-5}$ showed significant differences from the flanking regions of other $b l a_{\mathrm{KPC}}$ variants. Comparison of amino acid sequences with those of other KPC enzymes revealed that KPC-5 was an intermediate between KPC-2 and KPC-4, differing from KPC-2 by a single amino acid substitution $\left(\mathrm{Pro}_{103} \rightarrow\right.$ Arg), while KPC-4 contained $\mathrm{Pro}_{103} \rightarrow$ Arg plus an additional amino acid change $\left(\mathrm{Val}_{239} \rightarrow \mathrm{Gly}\right)$. The first 20 bases of the $b l a_{\mathrm{KPC}-5}$ are identical to corresponding region in $b l a_{\mathrm{KPC}-2}$, the next 65 bases showed no similarity with KPC-2 gene. [50].

Other variants (KPC-3 to KPC-5) differing from KPC-1/2 only two amino acid substitutions [39,43$44,50]$. DNA sequence analysis of the KPC-5 enzyme gene showed that was $99 \%$ identical to both $b l a_{\mathrm{KPC}-2}$ and $b l a_{\mathrm{KPC}-4}$ genes, with only single-nucleotide differences from either $\beta$-lactamase gene. The $b l a_{\mathrm{KPC}-5}$ had the same nucleotide substitution at position 308 $(\mathrm{C} \rightarrow \mathrm{G})$ as $b l a_{\mathrm{KPC}-4}$ compared with bla $_{\mathrm{KPC}-2}$, bla $_{\mathrm{KPC}-3}$, and $b l a_{\mathrm{KPC}-6}$, resulting in an amino acid change from proline to arginine. While $b l a_{\mathrm{KPC}-4}$ and $b l a_{\mathrm{KPC}-6}$ contained a guanosine at position 716, coding for a glycine amino acid, the $b l a_{\mathrm{KPC}-2}, b l a_{\mathrm{KPC}-3}$, and $b l a_{\mathrm{KPC}-}$ ${ }_{5}$ sequences differed at this nucleotide location, with a thymine residue, coding for a valine. The KPC-3 has 
the only gene to have a thymine substitution at position 814 (coding for tyrosine 272 ; His $(272) \rightarrow$ Tyr), whereas the other bla $_{\mathrm{KPC}}$ possessed a cytosine $[39,50]$.

The genetic relationships of the KPC-type $\beta$-carbapenemase variants we presented in figure 1 .

\section{Summary and conclusion}

Antimicrobial resistance due to the continuous selective pressure from widespread use of antimicrobials in humans, animals and agriculture has been a growing problem for last decades.

The occurrence of KPC-producing Gram-negative bacteria (mainly Klebsiella pneumoniae and other Enterobacteriaceae or Pseudomonas spp., Acinetobacter spp.) seems to be an emerging public health problem in various parts of the world [30,38], although, to date, widespread hospital outbreaks have been reported mainly in the United States $[11,26,46,51,63-67]$ and Israel $[8,43]$.

The recently, Greece [35,36], China [30-32] and some countries in South America seems to be the third facing a similar widespread problem $[8,28$ 29,33,36,49-50,56].

Dissemination of KPC enzymes among Gram-negative bacteria will seriously challenge the treatment of infections by these organisms. Infections due to bacteria producing KPC carbapenemases often have been associated with high mortality in affected patients $[31,34,68]$.

Clinical microbiology laboratories are becoming increasingly aware of the emergence of carbapenemase-producing organisms, but identification of such isolates remains difficult [69-72].

Therapeutic options to treat infections caused by multiresistant Gram-negative KPC-producers could be used polymyxin B [73], tigecycline [74] or probably in fast future combination a novel $\beta$-lactamase inhibitor (NXL104) with ceftazidime [75].

\section{Reference}

[ 1] Rodloff AC, Goldstein EJ, Torres A. Two decades of imipenem therapy. J Antimicrob Chemother. 2006;58(5):916-929.

[2] Dalhoff A, Janjic N, Echols R. Redefining penems. Biochem Pharmacol. 2006 30;71(7):1085-1095.

[3] Cao VB, Arlet G, Ericsson BM, Tammelin A, Courvalin P, Lambert T. Emergence of imipenem resistance in Klebsiella pneumoniae owing to combination of plasmid-mediated CMY-4 and permeability alteration. J Antimicrob Chemother. 2000;46:895-900.

[ 4] Wieczorek P, Sacha P, Hauschild T, Żórawski M, Krawczyk M, Tryniszewska E. Multidrug resistant Acinetobacter baumannii-the role of AdeABC (RND family) efflux pump in resistance to antibiotics. Folia Histochem Cytobiol. 2008;46(3): 257-267.

[ 5] Neuwirth C, Siébor E, Duez JM, Péchinot A, Kazmierczak A. Imipenem resistance in clinical isolates of Proteus mirabilis associated with alterations in penicillin-binding proteins. J Antimicrob Chemother. 1995;36(2):335-342.
[ 6] Thomson JM, Bonomo RA. The threat of antibiotic resistance in Gram-negative pathogenic bacteria: $\beta$-lactams in peril! Curr Opin Microbiol. 2005;8(5):518-524.

[ 7] Maltezou HC. Metallo- $\beta$-lactamases in Gram-negative bacteria: introducing the era of pan-resistance? Int J Antimicrob Agents. 2009;33(5):405.e1-405e.7.

[ 8] Navon-Venezia S, Chmelnitsky I, Leavitt A, Schwaber MJ, Schwartz D, Carmeli Y. Plasmid-mediated imipenemhydrolyzing enzyme KPC-2 among multiple carbapenemresistant Escherichia coli clones in Israel. Antimicrob Agents Chemother. 2006;50(9):3098-3101.

[ 9] Queenan AM, Bush K. Carbapenemases: the versatile $\beta$-lactamases. Clin Microbiol Rev. 2007;20(3):440-458.

[10] Sacha P, Żórawski M, Hauschild T, Wieczorek P, Jaworowska J, Jakoniuk P, Tryniszewska E. The presence of $b l a_{\mathrm{IMP}}$ genes on plasmids DNA isolated from multidrug-resistant Pseudomonas aeruginosa strains at University Hospital in Bialystok (Poland)-first report. Folia Histochem Cytobiol. 2007; 45(4):405-408.

[11] Deshpande LM, Rhomberg PR, Sader HS, Jones RN. Emergence of serine carbapenemases (KPC and SME) among clinical strains of Enterobacteriaceae isolated in the United States Medical Centers: report from the MYSTIC Program (1999-2005). Diagn Microbiol Infect Dis. 2006;56(4):367372.

[12] Sacha P, Wieczorek P, Hauschild T, Żórawski M, Olszańska D, Tryniszewska E. Metallo- $\beta$-lactamases of Pseudomonas aeruginosa - a novel mechanism resistance to $\beta$-lactam antibiotics. Folia Histochem Cytobiol. 2008;46(2):137-142.

[13] Hawkey PM, Jones AM. The changing epidemiology of resistance. J Antimicrob Chemother. 2009;64 Suppl 1:i3-i10.

[14] Walther-Rasmussen J, Hoiby N. Class A carbapenemases. $J$ Antimicrob Chemother. 2007;60(3):470-482.

[15] Ambler RP. The structure of $\beta$-lactamases. Philos Trans $R$ Soc Lond B Biol Sci. 1980;289(1036):321-331.

[16] Bush K, Jacoby GA, Medeiros AA. A functional classification scheme for $\beta$-lactamases and its correlation with molecular structure. Antimicrob Agents Chemother. 1995;39(6):12111233.

[17] Swarén P, Maveyraud L, Raquet X, Cabantous S, Duez C, Pédelacq JD, Mariotte-Boyer S, Mourey L, Labia R, NicolasChanoine MH, Nordmann P, Frere JM, Samama JP. X-ray analysis of the NMC-A $\beta$-lactamase at 1.64-A resolution, a class A carbapenemase with broad substrate specificity. J Biol Chem. 1998;273(41):26714-26721.

[18] Sougakoff W, L'Hermite G, Pernot L, Naas T, Guillet V, Nordmann P, Jarlier V, Delettré J. Structure of the imipenemhydrolyzing class A $\beta$-lactamase SME-1 from Serratia marcescens. Acta Crystallogr D Biol Crystallogr. 2002;58(Pt 2):267-274.

[19] Rasmussen BA, Bush K. Carbapenem-hydrolyzing $\beta$-lactamases. Antimicrob Agents Chemother. 1997;41(2):223-232.

[20] Yigit H, Queenan AM, Anderson GJ, Domenech-Sanchez A, Biddle JW, Steward CD, Alberti S, Bush K, Tenover FC. Novel carbapenem-hydrolyzing $\beta$-lactamase, KPC-1, from a carbapenem-resistant strain of Klebsiella pneumoniae. Antimicrob Agents Chemother. 2001;45(4):1151-1161.

[21] Mushtaq S, Ge Y, Livermore DM. Comparative activities of doripenem versus isolates, mutants, and transconjugants of Enterobacteriaceae and Acinetobacter spp. with characterized $\beta$-lactamases. Antimicrob Agents Chemother. 2004;48 (4):1313-1319.

[22] Giske CG, Sundsfjord AS, Kahlmeter G, Woodford N, Nordmann P, Paterson DL, Cantón R, Walsh TR. Redefining extended-spectrum $\beta$-lactamases: balancing science and clinical need. J Antimicrob Chemother. 2009;63(1):1-4.

[23] KPC-type $\beta$-Lactamases. Available at: http://www.lahey.org/ Studies/other.asp. Accessed August 24, 2009. 
[24] Yigit H, Queenan AM, Anderson GJ, Domenech-Sanchez A, Biddle JW, Steward CD, Alberti S, Bush K, Tenover FC. Novel carbapenem-hydrolyzing $\beta$-lactamase, KPC-1, from a carbapenem-resistant strain of Klebsiella pneumoniae. Antimicrob Agents Chemother. 2008;52(2):809.

[25] Yigit H, Queenan AM, Rasheed JK, Biddle JW, DomenechSanchez A, Alberti S, Bush K, Tenover FC. Carbapenemresistant strain of Klebsiella oxytoca harboring carbapenemhydrolyzing $\beta$-lactamase KPC-2. Antimicrob Agents Chemother. 2003;47(12):3881-3889.

[26] Bennett JW, Herrera ML, Lewis JS 2nd, Wickes BW, Jorgensen JH. KPC-2-producing Enterobacter cloacae and Pseudomonas putida coinfection in a liver transplant recipient. Antimicrob Agents Chemother. 2009;53(1):292-294.

[27] Naas T, Nordmann P, Vedel G, Poyart C. Plasmid-mediated carbapenem-hydrolyzing $\beta$-lactamase KPC in a Klebsiella pneumoniae isolate from France. Antimicrob Agents Chemother. 2005;49(10):4423-4424.

[28] Villegas MV, Lolans K, Correa A, Suarez CJ, Lopez JA, Vallejo M, Quinn JP; Colombian Nosocomial Resistance Study Group. First detection of the plasmid-mediated class A carbapenemase KPC-2 in clinical isolates of Klebsiella pneumoniae from South America. Antimicrob Agents Chemother. 2006;50(8):2880-2882.

[29] Villegas MV, Lolans K, Correa A, Kattan JN, Lopez JA, Quinn JP; Colombian Nosocomial Resistance Study Group. First identification of Pseudomonas aeruginosa isolates producing a KPC-type carbapenem-hydrolyzing $\beta$-lactamase. Antimicrob Agents Chemother. 2007;51(4):1553-1555.

[30] Wei ZQ, Du XX, Yu YS, Shen P, Chen YG, Li LJ. Plasmidmediated KPC-2 in a Klebsiella pneumoniae isolate from China. Antimicrob Agents Chemother. 2007;51(2):763-765.

[31] Cai JC, Zhou HW, Zhang R, Chen GX. Emergence of Serratia marcescens, Klebsiella pneumoniae and Escherichia coli isolates possessing the plasmid-mediated carbapenemhydrolyzing $\beta$-lactamase KPC-2 in intensive care units of a Chinese hospital. Antimicrob Agents Chemother. 2008;52(6): 2014-2018.

[32] Zhang R, Zhou HW, Cai JC, Chen GX. Plasmid-mediated carbapenem-hydrolyzing $\beta$-lactamase KPC-2 in carbapenemresistant Serratia marcescens isolates from Hangzhou, China. J Antimicrob Chemother. 2007;59(3):574-576.

[33] Zhang R, Yang L, Cai JC, Zhou HW, Chen GX. High-level carbapenem resistance in a Citrobacter freundii clinical isolate is due to a combination of KPC-2 production and decreased porin expression. $J$ Med Microbiol. 2008;57(Pt 3): 332-337.

[34] Marchaim D, Navon-Venezia S, Schwaber MJ, Carmeli Y. Isolation of imipenem-resistant Enterobacter species: emergence of KPC-2 carbapenemase, molecular characterization, epidemiology, and outcomes. Antimicrob Agents Chemother. 2008;52(4):1413-1418.

[35] Cuzon G, Naas T, Demachy MC, Nordmann P. Plasmid-mediated carbapenem-hydrolyzing $\beta$-lactamase KPC-2 in Klebsiella pneumoniae isolate from Greece. Antimicrob Agents Chemother. 2008;52(2):796-797.

[36] Giakoupi P, Maltezou H, Polemis M, Pappa O, Saroglou G, Vatopoulos A; the Greek System for the Surveillance of Antimicrobial Resistance. KPC-2-producing Klebsiella pneumoniae infections in Greek hospitals are mainly due to a hyperepidemic clone. Euro Surveill. 2009;14(21):1-5.

[37] Zavascki AP, Machado AB, de Oliveira KR, Superti SV, Pilger DA, Cantarelli VV, Pereira PR, Lieberkmecht AC, Barth AL. KPC-2-producing Enterobacter cloacae in two cities from Southern Brazil. Int J Antimicrob Agents. 2009;34(3): 286-288.

[38] Petrella S, Ziental-Gelus N, Mayer C, Renard M, Jarlier V, Sougakoff W. Genetic and structural insights into the dissem- ination potential of the extremely broad-spectrum class A $\beta$ lactamase KPC-2 identified in an Escherichia coli strain and an Enterobacter cloacae strain isolated from the same patient in France. Antimicrob Agents Chemother. 2008;52(10):37253736.

[39] Woodford N, Tierno PM Jr, Young K, Tysall L, Palepou MF, Ward E, Painter RE, Suber DF, Shungu D, Silver LL, Inglima K, Kornblum J, Livermore DM. Outbreak of Klebsiella pneumoniae producing a new carbapenem-hydrolyzing class A $\beta$ lactamase, KPC-3, in a New York Medical Center. Antimicrob Agents Chemother. 2004;48(12):4793-4799.

[40] Endimiani A, Carias LL, Hujer AM, Bethel CR, Hujer KM, Perez F, Hutton RA, Fox WR, Hall GS, Jacobs MR, Paterson DL, Rice LB, Jenkins SG, Tenover FC, Bonomo RA. Presence of plasmid-mediated quinolone resistance in Klebsiella pneumoniae isolates possessing $b l a_{\mathrm{KPC}}$ in the United States. Antimicrob Agents Chemother. 2008;52(7):2680-2682.

[41] Bratu S, Landman D, Alam M, Tolentino E, Quale J. Detection of KPC carbapenem-hydrolyzing enzymes in Enterobacter spp. from Brooklyn, New York. Antimicrob Agents Chemother. 2005;49(2):776-778.

[42] Deshpande LM, Jones RN, Fritsche TR, Sader HS. Occurrence and characterization of carbapenemase-producing Enterobacteriaceae: report from the SENTRY Antimicrobial Surveillance Program (2000-2004). Microb Drug Resist. 2006;12(4):223-230.

[43] Leavitt A, Navon-Venezia S, Chmelnitsky I, Schwaber MJ, Carmeli Y. Emergence of KPC-2 and KPC-3 in carbapenemresistant Klebsiella pneumoniae strains in an Israeli hospital. Antimicrob Agents Chemother. 2007;51(8):3026-3029.

[44] Alba J, Ishii Y, Thomson K, Moland ES, Yamaguchi K. Kinetics study of KPC-3, a plasmid-encoded class A carbapenemhydrolyzing $\beta$-lactamase. Antimicrob Agents Chemother. 2005;49(11):4760-4762.

[45] Bratu S, Mooty M, Nichani S, Landman D, Gullans C, Pettinato B, Karumudi U, Tolaney P, Quale J. Emergence of KPCpossessing Klebsiella pneumoniae in Brooklyn, New York: epidemiology and recommendations for detection. Antimicrob Agents Chemother. 2005;49(7):3018-3020.

[46] Moland ES, Hanson ND, Herrera VL, Black JA, Lockhart TJ, Hossain A, Johnson JA, Goering RV, Thomson KS. Plasmidmediated, carbapenem-hydrolysing $\beta$-lactamase, KPC-2, in Klebsiella pneumoniae isolates. J Antimicrob Chemother. 2003;51(3):711-714.

[47] Miriagou V, Tzouvelekis LS, Rossiter S, Tzelepi E, Angulo FJ, Whichard JM. Imipenem resistance in a Salmonella clinical strain due to plasmid-mediated class A carbapenemase KPC-2. Antimicrob Agents Chemother. 2003;47(4):12971300.

[48] Tibbetts R, Frye JG, Marschall J, Warren D, Dunne W. Detection of KPC-2 in a clinical isolate of Proteus mirabilis and first reported description of carbapenemase resistance caused by a KPC $\beta$-lactamase in P. mirabilis. J Clin Microbiol. 2008; 46(9):3080-3083.

[49] Robledo IE, Moland ES, Aquino EA, Vazquez GJ, Sante MI, Bertran J, and Hanson ND. 2007. First report of a KPC-4 and CTX-M producing $K$. pneumoniae isolated from Puerto Rico (PR), abstr. C2-1933, p.142. In Abstr. 47th Intersci. Conf. Antimicrob. Agents Chemother. American Society for Microbiology, Washington, DC.

[50] Wolter DJ, Kurpiel PM, Woodford N, Palepou MF, Goering RV, Hanson ND. Phenotypic and enzymatic comparative analysis of the novel KPC variant KPC-5 and its evolutionary variants, KPC-2 and KPC-4. Antimicrob Agents Chemother. 2009; 53(2):557-562.

[51] Chiang T, Mariano N, Urban C, Colon-Urban R, Grenner L, Eng RH, Huang D, Dholakia H, Rahal JJ. Identification of carbapenem-resistant Klebsiella pneumoniae harboring KPC 
enzymes in New Jersey. Microb Drug Resist. 2007;13(4):235239.

[52] Hossain A, Ferraro MJ, Pino RM, Dew RB 3rd, Moland ES, Lockhart TJ, Thomson KS, Goering RV, Hanson ND. Plasmid-mediated carbapenem-hydrolyzing enzyme KPC-2 in an Enterobacter spp. Antimicrob Agents Chemother. 2004; 48(11):4438-4440.

[53] Naas T, Cuzon G, Villegas MV, Lartigue MF, Quinn JP, Nordmann P. Genetic structures at the origin of acquisition of the

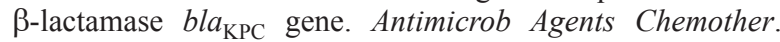
2008;52(4):1257-1263.

[54] Mendes RE, Bell JM, Turnidge JD, Yang Q, Yu Y, Sun Z, Jones RN. Carbapenem-resistant isolates of Klebsiella pneumoniae in China and detection of a conjugative plasmid (bla KPC-2 $_{2}$ plus qnrB4) and a bla $a_{\mathrm{IMP}-4}$ gene. Antimicrob Agents Chemother. 2008;52(2):798-799.

[55] Chmelnitsky I, Navon-Venezia S, Strahilevitz J, Carmeli Y. Plasmid-mediated qnrB2 and carbapenemase gene $b l a_{\mathrm{KPC}-2}$ carried on the same plasmid in carbapenem-resistant ciprofloxacin-susceptible Enterobacter cloacae isolates. Antimicrob Agents Chemother. 2008;52(8):2962-2965.

[56] Monteiro J, Santos AF, Asensi MD, Peirano G, Gales AC. First report of KPC-2-producing Klebsiella pneumoniae strains in Brazil. Antimicrob Agents Chemother. 2009;53(1): 333-334.

[57] Rice LB, Carias LL, Hutton RA, Rudin SD, Endimiani A, Bonomo RA. The KQ element, a complex genetic region conferring transferable resistance to carbapenems, aminoglycosides, and fluoroquinolones in Klebsiella pneumoniae. Antimicrob Agents Chemother. 2008;52(9):3427-3429.

[58] Rasheed JK, Biddle JW, Anderson KF, Washer L, Chenoweth C, Perrin J, Newton DW, Patel JB. Detection of the Klebsiella pneumoniae carbapenemase type 2 carbapenem-hydrolyzing enzyme in clinical isolates of Citrobacter freundii and $K$. oxytoca carrying a common plasmid. J Clin Microbiol. 2008; 46(6):2066-2069.

[59] Naas T, Vandel L, Sougakoff W, Livermore DM, Nordmann P. Cloning and sequence analysis of the gene for a carbapenem-hydrolyzing class A $\beta$-lactamase, Sme-1, from Serratia marcescens S6. Antimicrob Agents Chemother. 1994;38(6): 1262-70.

[60] Nordmann P. Trends in $\beta$-lactam resistance among Enterobacteriaceae. Clin Infect Dis. 1998;27 Suppl 1:S100-S106.

[61] Henriques I, Moura A, Alves A, Saavedra MJ, Correia A. Molecular characterization of a carbapenem-hydrolyzing class A $\beta$-lactamase, SFC-1, from Serratia fonticola UTAD54. Antimicrob Agents Chemother. 2004;48(6):2321-2324.

[62] Sarno R, McGillivary G, Sherratt DJ, Actis LA, Tolmasky ME. Complete nucleotide sequence of Klebsiella pneumoniae multiresistance plasmid pJHCMW1. Antimicrob Agents Chemother. 2002;46(11):3422-3427.

[63] Bratu S, Landman D, Haag R, Recco R, Eramo A, Alam M, Quale J. Rapid spread of carbapenem-resistant in New York City: a new threat to our antibiotic armamentarium. Arch Intern Med. 2005;165(12):1430-1435.

[64] Lomaestro BM, Tobin EH, Shang W, Gootz T. The spread of Klebsiella pneumoniae carbapenemase-producing
K. pneumoniae to upstate New York. Clin Infect Dis. 2006;43(3):e26-e28.

[65] Bratu S, Brooks S, Burney S, Kochar S, Gupta J, Landman D, Quale J. Detection and spread of Escherichia coli possessing the plasmid-borne carbapenemase KPC-2 in Brooklyn, New York. Clin Infect Dis. 2007;44(7):972-975.

[66] Nadkarni AS, Schliep T, Khan L, Zeana CB. Cluster of bloodstream infections caused by KPC-2 carbapenemase-producing Klebsiella pneumoniae in Manhattan. Am J Infect Control. 2009;37(2):121-126.

[67] Marschall J, Tibbetts RJ, Dunne WM Jr, Frye JG, Fraser VJ, Warren DK. Presence of the KPC carbapenemase gene in Enterobacteriaceae causing bacteremia and its correlation with in vitro carbapenem susceptibility. J Clin Microbiol. 2009;47(1):239-241.

[68] Mathers AJ, Cox HL, Bonatti H, Kitchel B, Brassinga AK, Wispelwey B, Sawyer RG, Pruett TL, Hazen KC, Patel JB, Sifri CD. Fatal cross infection by carbapenem-resistant Klebsiella in two liver transplant recipients. Transpl Infect Dis. 2009;11(3):257-65.

[69] Anderson KF, Lonsway DR, Rasheed JK, Biddle J, Jensen B, McDougal LK, Carey RB, Thompson A, Stocker S, Limbago B, Patel JB. Evaluation of methods to identify the Klebsiella pneumoniae carbapenemase in Enterobacteriaceae. J Clin Microbiol. 2007:45(8):2723-2725.

[70] Doi Y, Potoski BA, Adams-Haduch JM, Sidjabat HE, Pasculle AW, Paterson DL. Simple disk-based method for detection of Klebsiella pneumoniae carbapenemase-type $\beta$-lactamase by use of a boronic acid compound. J Clin Microbiol. 2008; 46(12):4083-4086.

[71] Tsakris A, Kristo I, Poulou A, Themeli-Digalaki K, Ikonomidis A, Petropoulou D, Pournaras S, Sofianou D. Evaluation of boronic acid disk tests for differentiating KPC-possessing Klebsiella pneumoniae isolates in the clinical laboratory. $J$ Clin Microbiol. 2009;47(2):362-367.

[72] Tenover FC, Kalsi RK, Williams PP, Carey RB, Stocker S, Lonsway D, Rasheed JK, Biddle JW, McGowan JE Jr, Hanna B. Carbapenem resistance in Klebsiella pneumoniae not detected by automated susceptibility testing. Emerg Infect Dis. 2006;12(8):1209-1213.

[73] Bratu S, Tolaney P, Karumudi U, Quale J, Mooty M, Nichani S, Landman D. Carbapenemase-producing Klebsiella pneumoniae in Brooklyn, NY: molecular epidemiology and in vitro activity of polymyxin B and other agents. J Antimicrob Chemother. 2005;56(1):128-132.

[74] Hawser SP, Bouchillon SK, Hoban DJ, Hackel M, Johnson $\mathrm{JL}$, Badal RE. Klebsiella pneumoniae isolates possessing KPC $\beta$-lactamase in Israel, Puerto Rico, Colombia and Greece. Int J Antimicrob Agents. 2009;34(4):384-385.

[75] Stachyra T, Levasseur P, Péchereau MC, Girard AM, Claudon $\mathrm{M}$, Miossec C, Black MT. In vitro activity of the $\beta$-lactamase inhibitor NXL104 against KPC-2 carbapenemase and Enterobacteriaceae expressing KPC carbapenemases. J Antimicrob Chemother. 2009;64(2):326-329.

Submittted: 26 July, 2009 Accepted after reviews: 13 October, 2009 